Wzniostość $i$ makabra w literackich obrazach śmierci, red. Michał Kuran, Łódź 2014, „Analecta Literackie i Językowe", t. IV.

\title{
FUNKCJONOWANIE MOTYWU ŚMIERCI W POLSKICH POWIEŚCIACH GROZY POCZĄTKU XIX WIEKU NA PRZYKŁADZIE TWÓRCZOŚCI AnNy Mostowskiej I Łucji Rautenstrauchowej
}

Zjawisko gotycyzmu w literaturze polskiej przełomu XVIII i XIX wieku stanowi jakby odrębną niszę wpisującą się w nurt tendencji preromantycznych, pozostając przy tym znikomym ogniwem ojczystego pisarstwa, integrującym zwiastuny romantyczne zachodu z późniejszymi inklinacjami na gruncie rodzimym. Nowy nurt odkrywa uroki świata pozazmysłowego, metafizycznego, posługując się estetyką strachu, koszmaru, upiorności i mroku. Próby zasymilowania i przeszczepienia rozkrzewionego na zachodzie romansu gotyckiego do pisarstwa ojczystego podjęła się jako pierwsza Anna Mostowska. Jednakże tak ona, jak i jej następcy (między innymi Łucja Rautenstrauchowa), mając świadomość, że wprowadzają tematy, delikatnie mówiąc, kontrowersyjne w stosunku do klasycystycznej koncepcji literatury czasów stanisławowskich, dodatkowo nadawali tej szerzonej przez siebie niezwykłości charakter dydaktycznowychowawczo-moralizatorski lub łagodzili tę niesamowitość, uprawdopodobniając akcję. Niemniej jednak to za ich przyczyną wprowadzone zostały takie romantyczne rekwizyty, jak na przykład: duchy, mary, upiory, postaci świętych pustelników, obłąkanych z miłości kobiet czy nimf kuszących młodzieńców, jak również motywy przedśmiertnej spowiedzi czy łączenie obrzędów chrześcijańskich z pogańskimi i wiele innych. Dodatkowo pokusiły się również o nadanie swojej twórczości nowej formy - romansu, który był raczej krytykowany za zgubny wpływ na morale, zwłaszcza młodzieży. Dawano wówczas do zrozumienia, że utwory należące do tego gatunku nie powinny trafić $\mathrm{w}$ ręce młodego pokolenia, gdyż ono z lubością identyfikuje się z bohaterami miłosnych historii, dążąc do ułożenia swojego życia zgodnie z literackim scenariuszem. Jak zauważył Bronisław Gubrynowicz:

Skutki tego bywały opłakane. Młode panny z niechęcią myślały o czekającej je roli żon, matek i pań domu, a jako dojrzałe kobiety tęskniły u boku mężów do idealnych amantów, o których naczytały się

\footnotetext{
${ }^{1}$ Monika Kusek — urodziła się 05 maja1985 roku w Radomsku. Studia magisterskie w zakresie filologii polskiej ukończyła na Uniwersytecie Jana Kochanowskiego — Filia w Piotrkowie Trybunalskim. Obecnie jest doktorantką II roku literaturoznawstwa na Akademii im. Jana Długosza w Częstochowie. Do jej zainteresowań należy zjawisko gotycyzmu w literaturze, malarstwie i filmie. Współpracuje z Kołem Literackim „Anafora”. Publikowała m.in. w „Horyzontach”, „Studiach Słowianoznawczych”, „Tygodniu Trybunalskim” oraz wydawanym przez UJK „Kalejdoskopie Uniwersyteckim”.
} 
w młodości. Nastoletni chłopcy marzyli o heroinach, jakich nie mieli nigdy spotkać w szlacheckich dworkach Mazowsza czy Polesia ${ }^{2}$.

W romansie gotyckim przełomu XVIII i XIX wieku niezwykle często pojawiają się makabryczne, ale i wzniosłe sceny śmierci. Pełnią one szczególną funkcję: często współgrają z tłem. Zależnie od podejmowanej tematyki, która albo zbliża się do sentymentalnych krajobrazów, albo też, przyjmując formę tzw. „terror gothic” przepełnioną całą gamą drastycznych scen, mamy do czynienia z dwoma ich wariantami: makabrą i wzniosłością.

Specyficzny sposób ujęcia tematu śmierci zaprezentowany w powieściach gotyckich, zmierzający w kierunku wyostrzenia jej wariantów makabrycznych, będących jakby prekursorską formą naturalistycznych obrazów, ma konkretny cel wynikający jeszcze z myśli oświeceniowej, a mianowicie desakralizacji zjawiska śmierci, odejścia od traktowania jej jako jarzma nałożonego na człowieka, swoistego rodzaju kary za grzechy pokazującej, że potrzebuje on wsparcia Boga i że sam w sobie jest niczym. Według Pawła Lisiciego,

właśnie tak pojmowaną śmierć musiało w imię człowieka i jego autonomii odrzucić Oświecenie. Musiało sprowadzić ją do jednego z wielu zjawisk rozkładu, jakie napotykamy w przyrodzie, do części wielkiego procesu umierania i rodzenia się na nowo. [...] Oczywiście, nie można było zniszczyć śmierci samej w sobie, zamiast tego zniszczono jej dawne znaczenie ${ }^{3}$.

Ówcześni pisarze chętniej szafowali „naturalistycznymi” opisami zgonu. Niektórzy, być może dlatego, że pragnęli wcielić w życie teorię filozoficzną Edmunda Burke’a, przedstawioną w pracy A Philosophical Enquiry into the Origin of our Ideas of the Sublime and Beautiful, zgodnie z którą „lęk przed śmiercią jest najsilniejszym rodzajem trwogi i dopiero jego doznanie najlepiej pozwala nam doświadczyć uczucia wzniosłości”‘ .

W pierwszym okresie powieściopisarze zajmowali się zagadnieniem wzniosłości tylko w zakresie estetyki jako czynnikiem, który przy użyciu odpowiednich atrybutów wznieca w czytelnikach wrażenie majestatyczności i grozy. Wzorem takich dzieł literatury europejskiej są Zamczysko w Otranto Horacego Walpole'a, Mnich Matthew Gregory’ego Lewisa czy Italczyk Ann Radcliffe. Kierując się przekonaniem, iż najintensywniejszym doświadczeniem niepokoju jest obawa przed śmiercią, autorzy romansów grozy często podejmują motyw kresu życia. Zgodnie ze spostrzeżeniem Manuela Aguirre, to właśnie gotycyzm jest formą otwarcia się na lęk metafizyczny, co za tym idzie, strach przed śmiercią̧5.

\footnotetext{
${ }^{2}$ B. Gubrynowicz, Romans Polsce za Stanistawa Augusta, Lwów 1904, s. 6-7.

${ }^{3}$ P. Lisicki, Mroczne dziedzictwo Oświecenia, [w:] tenże, Nie-ludzki Bóg, Warszawa 2007, s. 37.

${ }^{4}$ Cyt. za. A. Łowczanin-Łaszkiewicz, Motyw śmierci w wybranych angielskich powieściach gotyckich: „Zamczysko w Otranto” H. Walpole'a, "Italczyk” A. Radcliffe i „Mnich” M. G. Lewisa, [w:] Gotycyzm i groza $w$ kulturze, red. G. Gazda, A. Izdebska, J. Płuciennik, Łódź 2003, s. 23.

${ }^{5}$ Zob. M. Aguirre, Geometria strachu. Wykorzystanie przestrzeni w literaturze gotyckiej, [w:] Wokót gotycyzmów. Wyobraźnia, groza, okrucieństwo, red. G. Gazda, A. Izdebska, J. Płuciennik, Kraków 2002.
} 
Fundamentalne znaczenie posiada tu więc pierwiastek metafizyczny, obowiązkiem jest również wykreowanie średniowiecznego tła, które miało tworzyć scenerię dla przygód postaci uciekających przed śmiercią. Te z kolei zaliczają się do kręgu dobrych, światłych bohaterów lub złych, żądnych krwi złoczyńców. Toteż świat przedstawiony osiemnastowiecznego romansu gotyckiego -

[...] opiera się na skonwencjonalizowanej fabule (obecność takich motywów, jak: ucieczka, rozdzielenie kochanków, tajemnica wyjawiona w przedśmiertnej spowiedzi czy zemsta zza grobu), postaciach stanowiących raczej typy niż indywidualności (dręczona dziewczyna, knujący jej zgubę łotr, mnich-intrygant lub zbrodniarz, szlachetny wybawiciel) oraz specyficznej strukturze ewokującej niepokój i poczucie zagrożenia ${ }^{6}$.

Była to zatem wzniosłość, jednakże zobowiązująca do realizacji sprecyzowanych kryteriów, przyjęcia atrybutów charakterystycznych dla gatunku. Można dojść do wniosku, że była to wzniosłość nieco wymuszona i sztuczna.

Jednakże w polskich powieściach grozy to nie sama „wzniosłość” staje się celem najważniejszym.

Bliższy pełnym patosu obrazom wydaje się być dorobek Łucji Rautenstrauchowej, zaliczany przez Barbarę Czwórnóg-Jadczak do drugiego etapu polskiej powieści gotyckiej określanego mianem twórczości oświeceniowo-preromantycznej ${ }^{7}$, gdzie cechy romantyzmu mieszają się z realizmem obyczajowym i historycznym. Dodatkowo Rautenstrauchowa, aby bardziej uprawdopodobnić akcję powieści, nadaje jej charakter historii zasłyszanej i wypowiedzianej przez jednego z bohaterów. Oparta o tradycyjny schemat powieści zaliczanej do nurtu sentimental gothic - Ragana prezentuje parę zakochanych w sobie młodych ludzi: Juliana i Errinę, którzy jednak z woli rodziców zostają rozłączeni. Cała późniejsza akcja to opis przeszkód, jakie pokonują bohaterowie, jak na przykład choroby prowadzące do obłędu, dalekie podróże, wyzwolenie się spod władzy zaborczej kobiety. Kiedy wydawać by się mogło, iż młodzi ludzie mają już za sobą najgorsze chwile życia, trudności, a cała powieść będzie jedynie nużącym sentymentalnym obrazkiem, wówczas tuż po ślubnych przyrzeczeniach Errina umiera. Scena śmierci, choć jest zaskakująca, nie ma powiązania z jakąś nadprzyrodzoną mocą, to wynik raczej fizycznego cierpienia, choroby, czego dowodzi opis: „zdawała się usypiać, lecz twarz jej zupełnie zmieniona była. Usta zsiniałe, oczy wpadłe, bladość biała, w śniady się kolor zmieniła" (Ragana, t. 2., rozdz. XVIII, s. 292) ${ }^{8}$.

Natomiast wzniosły i typowo sentymentalny obraz stanowi swoistego rodzaju scena pożegnania z najbliższymi, wola przebaczenia i widok otaczającego umierającą światła

${ }^{6}$ M. Drabikowska, Świat przedstawiony powieści gotyckiej — przestrzeń martwa i ewokująca śmierć, [w:] Kulturowe obrazy śmierci od przetomu romantycznego do dzis. Materiaty studenckiej konferencji naukowej, Łódź, 25-27 października 2006 r., red. I. Grzelak, T. Jermalonek, Łódź 2007, s. 155.

${ }^{7}$ B. Czwórnóg-Jadczak, Polska powieść gotycka początku XIX wieku. (Z zagadnień historycznych przeobrażeń gatunku), [w:] Z problemów poetyki historycznej, red. L. Ludorowski, Lublin 1984, s. 127.

${ }^{8}$ Ł. Rautenstrauchowa, Ragana czyli ptochość, Warszawa 1830, [ on-line], dostęp 2013 maja 20, dostępny: <http://www.pbi.edu.pl/book_reader.php?p=50091\&s=1>, s. 292 (pozostałe cytaty za tym wydaniem). 
i zmarłej przedwcześnie matki, która teraz wyciąga ręce po swoje dziecko. Wyznania na łożu śmierci w tym przypadku nie służą przerażeniu, a nawet wydają się być furtką do wiecznej szczęśliwości.

Tego typu śmierć niekoniecznie służy zbudowaniu atmosfery grozy, pisarka w tym momencie nie wykorzystuje całego jej potencjału jako źródła lęku, co nie oznacza jednak, że i bohaterom, i czytelnikowi nie towarzyszy przeżycie wzniosłości, bynajmniej, wynika ono z innego źródła niż lęk i przerażenie. Mimo wszystko jest to też śmierć spektakularna, gdyż do jej obserwatorów należy cała świta, goście zgromadzeni z okazji ceremonii zaślubin. Rautenstrauchowa buduje napięcie za pomocą różnorodnych środków: sama okoliczność śmierci jest dramatyczna, gdyż ma ona miejsce tuż po uroczystościach ślubnych, dodatkowo wszystko dzieje się w mrocznej, przypałacowej świątyni.

Według Zofii Sinko, koncepcja wprowadzenia sceny śmierci do przestrzeni sakralnej, jaką jest kaplica, nawiązywała do rozpowszechnionej wówczas „cmentarnej poezji” angielskiej.

Straszliwą ponurość (a formidable gloom) starych, przycmentarnych kościołów i grobowych krypt opisują w połowie wieku tzw. poeci nocy i grobów, a szczególnie Robert Blair w poemacie The grave, w którym wyobraźnia poety ewokuje gloomy aisles — ponure nawy i low vaults — niskie krypty gotyckie wiejskiego kościółka, wokół którego przechadzają się bezszelestnie smutne duchy9?

Mamy więc w przypadku Ragany, zdaniem Magdaleny Drabikowskiej, do czynienia z:

[...] fascynacją miejscami jednoznacznie definiowanymi jako przestrzenie śmierci. W świecie przedstawionym powieści gotyckiej bohaterowie, którzy tam wkraczają (lub zostają do wejścia zmuszeni), oddają się jej. Zejście do podziemi pośród trumny i szkielety, cmentarz, grobowa kaplica antycypują często nagłe i gwałtowne umieranie, jak to się dzieje w przypadku Lewisowskiej Antonii więzionej w spełniających rolę grobowca klasztornych podziemiach i tam zamordowanej, czy Matyldy, bohaterki Zamczyska $w$ Otranto Horacego Walpole’a, którą śmierć dosięga w zamkowej kaplicy ${ }^{10}$.

Kres jej życia wydaje się być tożsamym z tym, co dosięga Errinę — bohaterkę powieści Rautenstrauchowej. Nie ma tu jednak takiej obfitości niezwykłości, jak w innych romansach gotyckich. Jak zauważyła Agnieszka Łowczanin-Łaszkiewicz:

Czytelnik nie jest zatem wystarczająco przerażony, a napięcie emocjonalne nie jest wystarczająco silne, a przecież tego oczekujemy sięgając po romanse grozy ${ }^{11}$.

Niemniej jednak scena śmierci staje się w tym momencie wydarzeniem kluczowym, zatrzymuje akcję, rozbudza ciekawość czytelnika odnośnie późniejszych wypadków.

${ }^{9}$ Por. Z. Sinko, Gotyk i ruiny w wyobraźni literackiej epoki oświecenia, „Przegląd Humanistyczny” 1978, nr 9, s. 26.

${ }^{10}$ M. Drabikowska, dz. cyt., s. 156.

${ }^{11}$ A. Łowczanin-Łaszkiewicz, dz. cyt., s. 25. 
Przeżycia, jakich doświadcza zakochany w Errinie Julian po jej śmierci, zmieniają jego psychikę z sentymentalnego kochanka w zwyrodnialca pałającego żądzą zemsty. Nie można go mimo wszystko identyfikować z grupą czarnych charakterów, morderców tak charakterystycznych dla powieści grozy, niemniej jednak podobnie jak oni starannie planuje wyrafinowaną zemstę. Z obłąkańczą pasją poświęca się realizacji swoich planów rozprawienia się z kobietą, która stała się przyczyną rodzinnych tragedii. Zadając jej ból, dąży do zdominowania Walerii, wzbudza w niej nieopanowany strach:

Oprawca zdaje sobie sprawę z cierpienia ofiary i wiedza ta zachęca go do eskalacji tortur. [...] Będąc szafarzem cierpienia i strachu ofiary, oprawca uzasadnia swoje działanie potrzebom podporządkowania jej sobie, aby postępowała zgodnie z jego wolą i celem ${ }^{12}$.

Julian wierzy, że zastraszając Walerię, doprowadzi ją do uległości — „okrutny wychowawca zadaje wychowankowi cierpienie i wywołuje w nim paraliżujący lęk w imię poprawy moralnej"13. Choć jego celem nie jest morderstwo, to jednak przygotowuje swoistego rodzaju celę, jeśli nie śmierci, to na pewno tortur, ukryte w środku puszczy pieczary, lochy, których nikt nie odwiedza twierdząc, że to miejsce przeklęte. Z największym okrucieństwem traktuje swoją ofiarę; przywiązując ją łańcuchami i kajdanami, doprowadzając do omdlenia i konwulsji, które odtąd stale jej towarzyszą. Od tej chwili jej egzystencja jest nieustannym obcowaniem ze śmiercią. Julian stosuje wobec niej także przemoc psychiczną:

Przysposobiłem jednak rozmaite przedmioty, stosowne do wzbudzenia w tobie miłych wspomnień przeszłości.

Oto przed tobą spoczywa ciało tej, którąś do grobu wtrąciła, tu zaś w tym poszycie, opisanie jej cierpień. Będziesz mogła co dzień po kilka jego kartek z uwagą odczytywać, tak jak pobożniejsi od ciebie, życie świętych czytają; rozmyślać nad pięknym twym czynem, unosić się nad chwalebnymi jego skutkami. Ten łańcuch, który pozwolisz, żeby ci za przepaskę teraz służył, będzie jedynie zachętą dla ciebie, żebyś się moim zamiarom nie przeciwiła, żeby ci szkodliwą myśl ucieczki nie dopuścić...

(Ragana, t. 3, rozdz. IV, s. 48)

To, co bohaterowi wydaje się być wzniosłym uczczeniem pamięci ukochanej kobiety, przybiera postać perwersji, makabry i naturalistycznych opisów.

Julian, zadając fizyczny ból swojej ofierze, odczuwa wewnętrzną ulgę. Na co dzień obcuje ze śmiercią; już w dniu zgonu Erriny postanowił wykraść jej ciało i zamieszkać razem z nim. Ukrywał się w przebraniu mnicha, niczym tradycyjni zuchwalcy z gotyckich romansów, co więcej, sporządzonym z kiru, którym obita była kaplica po śmierci Erriny. Odseparował się również od społeczeństwa, co być może wpłynęło na jego system moralny, kanon wartości - z czasem odchylający się od ogólnie przyjętego. Pierwsze miejsce zajmuje w nim miłość i chęć pomszczenia ukochanej. Oddaje się jej cały z pasją, poświęceniem i egzaltacją.

Kreując postać Juliana, Łucja Rautenstrauchowa udowadnia, że „niepopełniona zbrodnia może wywołać w czytelniku silniejszą trwogę niż dostarczenie kolejnego

${ }_{12}$ P. Łuków, Moralność okrucieństwa, [w:] Gotycyzm i groza w kulturze, 193.

${ }^{13}$ Tamże, s. 193. 
trupa" ${ }^{14}$. Oscylowanie na granicy śmierci powoduje przez przybliżenie jej fizycznych oznak (jak na przykład obraz trumny ze zwłokami Erriny, ale również przez profesjonalne wykorzystanie potencjału tkwiącego w napawającej lękiem i niepewnością grze światłem i cieniem, ciszą i dźwiękiem, obrazach wrogiej, zamkniętej przestrzeni, opisach dołów nikomu nieznanych, leżących w samym środku puszczy, niedostępnych dla zwykłego człowieka oraz otwartej przestrzeni lasu uświadamiającej bohaterom znikomość ich istnienia) zintensyfikowanie zagrożenia nią. Miejsce to epatuje atmosferą śmierci. Położone jest w niedostępnej okolicy, wyraziście wyizolowane w planie wertykalnym na podobieństwo gotyckiego zamku. To terytorium śmiertelnego niebezpieczeństwa zarazem dla Juliana i Walerii, jak i obcych, pochodzących z zewnątrz.

Taki sposób zaznajomienia z obrazem śmierci można by określić jako wysublimowaną fazę terror gothic, tym bardziej że każdy kolejny zgon, choć to nie elementy nadprzyrodzone mają tu największe znaczenie, niesie za sobą pewną niezwykłość, niepospolitość, stając się elementem kompozycyjnym spinającym kolejne tomy powieści.

Świat przedstawiony po śmierci Erriny nie powraca bynajmniej do starego, naturalnego porządku. Zaburzenie jego pierwotnej harmonii i nasycenie eterem śmierci ma swoje odzwierciedlenie także w specyficznym kształtowaniu warstwy językowej. Eskalacja przerażenia następuje $\mathrm{w}$ chwili, kiedy bohater przekonany jest o tym, że widzi widmo zmarłej ukochanej, dlatego język opisujący jej pojawienie się wywołuje grozę i strach:

Blask księżyca właśnie na nią pada, od samej głowy przykryta, twarzy, oczu, nóg nawet nie widać, bardzo pomału się posuwa, jednak w poruszeniu ręki stronę prężącej, zdaje mu się coś podobnego do przedmiotu pierwszej swej miłości upatrywać. Serce jego gwałtownie bije... Coraz prędzej bieży wnet się przekona, czy to złudzenie obłąkanych zmysłów, czyli też podług zbyt upowszechnionego mniemania, jeden z tych duchów, co ani do rzędu ludzi, ani do Aniołów nienależące, lecz między niemi środkując, świat ten czasem zwiedzają... Już niedaleko... już dościga.

(Ragana, t. 2, rozdz. VII, s. 93-94)

Stan Juliana Rautenstrauchowa opisuje, używając frazeologizmów i hiperbolizacji: „Nogi drżą pod Julianem, szybkim jednak krokiem pośpiesza ku niej [...] Serce jego gwałtownie bije... Coraz prędzej bieży..." (Ragana, t. 2, rozdz. VII, s. 93-94), czym sugeruje, że dla oddania grozy pojawiającego się widma nie wystarczy zwykłe „był przerażony”.

Zdarza się kolejny zgon. W czasie narracyjnym utworu jest to tragiczna śmierć, w pewnym sensie niezwykła, bo przewidziana i dokładnie zaplanowana przez bohatera. Julian, spodziewając się kresu życia, poczynił odpowiednie przygotowania. Sam wykopał grób, zgromadził pamiątki i wydał zalecenia Walerii: „na grobowcu moim położysz jak cię już oto prosiłem, zasuszone fiołki i lutnią które przy mnie znajdziesz” (Ragana, t. 3, rozdz. VIII, s. 100). Julian dąży więc do zachowania namiastki kontaktu z Errina, zabierając relikwie pozostałe po ich ostatnim spotkaniu. Nie jest w stanie rozstać się z nią nawet po śmierci.

${ }^{14}$ A. Łowczanin-Łaszkiewicz, dz. cyt., s. 27. 
[...] resztę zaś dnia często przepędzał na kopaniu dołu dla siebie obok trumny żony swojej, co dzień błagając Przedwiecznego, aby jak najprędzej pozwolił mu używać tego mieszkania.

(Ragana, t. 3, rozdz. V, s. 59)

Przejście na drugi świat nie jest dla niego bynajmniej kresem uczucia, zapewne tkwi on w przekonaniu, że dusze kochanków jest w stanie połączyć dopiero śmierć, także ich ciała spoczywają obok siebie. Jest to jak najbardziej zgodne z konwencją romansu gotyckiego, gdzie typowym zakończeniem jest zgon głównych bohaterów w dramatycznych, pełnych grozy okolicznościach. W powieści Rautenstrauchowej kryterium to realizuje nie tyle odejście Erriny, poprzedzone obłędem i ciężką chorobą, co zgon Juliana — niesamowity, tajemniczy, zharmonizowany z jego obłąkańczą miłością. Tak naprawdę jego śmierć nie jest spowodowana fizycznym niedomaganiem, lecz chorobliwą miłością doprowadzającą do szaleństwa.

Najbardziej jednak niezwykły obraz śmierci to scena konania Walerii — prawdziwej femme fatale, kobiety będącej przyczyną trosk wszystkich pozostałych bohaterów, kierującą się w swoich poczynaniach nie rozsądkiem czy nawet uczuciami, lecz tzw. „płochością”, równoznaczną z niestabilnością charakteru, namiętnością, instynktownymi wyborami, niestabilnością emocjonalną i uczuciową, postępującą zawsze zgodnie z zasadą, że „zakochanej kobiecie wolno wszystko”:

A potem cóż jest nagannego w moich czynnościach — mówi? Ujrzałam Juliana, podobał mi się, wolna jestem, młoda, piękna, starałam się mu nawzajem podobać, nic naturalniejszego. W takim razie wszystko wolno. Nikt ani może, ani ma prawo mię sądzić.

(Ragana, t. 2, rozdz. I, s. 4-5)

Więziona przez Juliana i poddawana „torturom” psychicznym, w końcu uznaje racje swojego obłąkanego oprawcy, przysięga odkupić swoje winy przez dziesięć lat pokutując w wyznaczonym przez Juliana miejscu, a kiedy wydawać by się mogło, że ma szanse na powrót do normalnego życia, jakaś wyższa siła wymierza sprawiedliwość. Sama natura skazuje ją na śmierć. Wejście do jej lochu zapada się, a uwolnieniu na wpół żywej kobiety towarzyszy niezwykła reakcja przyrody:

[...] okropny wicher, gęste niosący kurzu tumany. Niebo się czarnymi przykryło chmurami i tylko błyskawice przeszywając je niekiedy, krwawy swój blask na zsiniałą twarz Waleryi rzucały!

(Ragana, t. 3., r. XIX, s.241)

Sam obraz konania przypomina nie tyle opisy charakterystyczne dla romansów grozy, co późniejsze naturalistyczne obrazy reakcji fizjologicznych w czasie agonii:

[...] Ręce jej pogryzione, odzienie, piersi w rozpaczy poszarpane, we krwi broczyły! [...] Zdawała się ciągle okropnie cierpieć, rękę na sercu trzymała jakby w nim nieznośny ciężar czuła, wyraz jej twarzy był przykrą boleścią przejęty, oczy krwią zaszłe, na wszystkie się przewracając strony, trwogę i rozpacz malowaty!

Wtem piorun, z przeraźliwym trzaskiem o kilkadziesiąt padając kroków, wstrząsł ziemię. Przestrach ten wprawił ją w konwulsje, które i dawniej za każdym przelęknieniem miewała, a wpośród nich męczarnie swoje i życie skończyła.

(Ragana, t. 3, rozdz. XIX, s. 241-243) 
Ragana to powieść gotycka, która nie jest pozbawiona cudownego aparatu. Rolę wymiaru sprawiedliwości odgrywa tu bowiem sama przyroda, a ów zgon jest realizacją moralnego zadośćuczynienia w duchu swoiście rozumianej sprawiedliwości.

Również druga powieść Łucji Rautenstrauchowej — Przeznaczenie traktuje śmierć jako jeden z elementów gotyckiej rekwizytorni, a nawet wysuwa go na plan pierwszy jako źródło estetycznego przekazu. „To »emblematy śmierci« — zarówno jej fizyczne przejawy, jak i emocje, których wywołaniu ma służyć, wydają się stanowić estetyczne i emocjonalne jądro utworu" 15 .

Wkroczywszy w świat powieściowy, już pierwszą sceną, którą czytelnik dostrzega, jest obraz młodej kobiety przybranej w strój żałobny:

Żałobną szatą odziana, młoda niewiasta, spoczywa niedbale na sofie; alabastrowa lampa, mdłe na nią rzuca światło; przetwarta książka z rąk jej wypadła; a tęskność na licach rozlana i częste westchnienia, głęboki smutek zdradzają ${ }^{16}$.

(Przeznaczenie, t. 1., rozdz. I, s. 9)

Jak widać, emocjonalny język powieści gotyckich burzy reguły składni i decorum, wprowadzając wrażenie chaosu, a czasowniki umieszczone zwykle w końcowej części zdania dodają tekstowi retoryczności i patosu, i co za tym idzie, wywołują wrażenie wzniosłości.

Jak się później okazuje, przyczyną smutku i żałoby dziewczyny jest śmierć jej ojca. Sam opis Heleny dotyczący okoliczności jego zgonu wydaje się być wyjątkowy. Brak tu ciemnych przymiotników i opisujących bądź ewokujących grozę metafor, zdania są chłodne, pozbawione wzniosłości towarzyszącej opisom innych scen śmierci. Relacja Heleny wygląda następująco:

To tylko wiemy, iż wracając z wód zatrzymał się dzień jeden w jednym z czeskich miasteczek, tam wstawszy z rana poszedł między góry, a w godzinę wrócił, ledwo już idąc o swej sile, i cały krwią zbroczony. Piersi miał strzałem przeszyte i we dwa dni żyć przestał.

(Przeznaczenie, t. 1, rozdz. I, s. 11)

Cała późniejsza akcja romansu koncentruje się na dążeniu do wyjaśnienia okoliczności tego zgonu i chęci jego pomszczenia.

Początkowo Przeznaczenie wydaje się być historią obyczajową, pozbawioną niezwykłości czy grozy, tak charakterystycznych dla powieści gotyckich. W realiach początku XIX wieku Helena przyżywa swoją żałobę, całe dnie spędzając w kaplicy (miejscu zwanym „Górą Spoczynku”), gdzie złożone zostały szczątki jej rodziców:

Na szczycie wyniosłej góry, skąd oko dalekie odkrywa niwy, widać pod cieniem kilku świrków i wierzb płaczących piękną raczej niż okazałą kaplicę.

(Przeznaczenie, t. 1, rozdz. III, s. 35)

\footnotetext{
${ }^{15}$ A. Łowczanin-Łaszkiewicz, dz. cyt., s. 29.

${ }^{16}$ Ł. Rautenstrauchowa, Przeznaczenie, Warszawa 1831 [on-line], dostęp 2013 maja 20, dostępny: $<$ http://pbi.edu.pl/book_reader.php?p=50081\&s=1>s. 9 (pozostałe cytaty z tego wydania).
} 
Pewien element tajemniczości i niezwykłości wkracza do akcji powieści wraz z pojawiającą się postacią młodego pustelnika, który przykuwa uwagę Heleny. Dodatkowo nastrój grozy podsyca cygańska przepowiednia, jaką dziewczyna słyszy w dniu swoich urodzin: „Zabójca ojca jest twoim bratem! — A brat twój małżonkiem twej duszy. A dusza twoja za życia piekielnych dozna katuszy!!" (Przeznaczenie, t. 1, rozdz. VII, s. 80).

Dziewczyna bagatelizuje tę wróżbę, nie zdając sobie sprawy, jak szybko przekona się o jej prawdziwości, a wybranek jej serca okaże się być jednocześnie jej przyrodnim bratem i ojcobójcą.

Zawiedzione uczucie i traumatyczne przė̇ycia skłaniają młodą kobietę do szukania pocieszenia w klasztorze. Nie może ona nawet przypuszczać, że owa przestrzeń sakralna, święta, stanie się jednocześnie więzieniem dla niej, celą śmierci. Helena w momencie, kiedy wkracza w otoczenie kościelnych grobowców, by tam po raz ostatni ujrzeć przyrodniego brata, żegnając się z nim, nie spodziewa się, że przerażający widok otaczających ją krypt będzie towarzyszyć jej do końca jej dni, a za czuły gest wobec niego kierunku będzie musiała przypłacić życiem. Fakt spotkania zostaje odkryty przez nową przeoryszę klasztoru i opacznie zrozumiany. Za spotkanie z mężczyzną dziewczyna ma ponieść zdumiewającą karę. Zostaje wtrącona do klasztornych lochów, gdzie trupie opary i samotne życie mają jej dopomóc w odpokutowaniu popełnionego grzechu.

Wyrokowi śmierci, który ma zapaść za przewinienia młodej zakonnicy, towarzyszy specyficzny sąd swoją formą zbliżający się do Świętej Inkwizycji. Z mocy wyroku ferowanego przez Święte Oficjum, Helena zostaje skazana na zamurowanie żywcem.

Ta, która za występek jakiegoś się dopuściła w trzydziestym czwartym przepisania jest artykule, stanowi tylko wieczne więzienie, z pozbawieniem światła słonecznego, z zamurowanymi na zawsze drzwiami i...

Nie słyszała końca wyroku swego nieszczęśliwa Helena. Od pierwszych słów Panny Matki, całe męstwo ją odstąpiło, dreszcz śmiertelny po wszystkich członkach przeszedł, siły opuściły.

(Przeznaczenie, t. 2, rozdz. X, s. 126)

W tym momencie widać korelację pomiędzy gotycyzmem a średniowieczem. Historycznie rzecz ujmując, gotycyzm należy do wyobrażeń świata chrześcijańskiego. I chociaż fascynacja wiekami średnimi odnosi się także do tradycji religijnej, to jednak, jak to widać w tym przypadku, poetyka grozy wydobywa na światło dzienne swoje, często występne, a niejednokrotnie również zbrodnicze, oblicze. Przeciwstawiamy się przypisywaniu mu pewnej formy sacrum, uznając go co najwyżej za świętokradztwo. W swojej wymowie symbolicznej gotycyzm odwołuje się do znaczenia przemocy, ofiary, upokorzenia, walki dobra ze złem, logiki paradoksu, konstytuujących średniowieczną religijność.

Sceneria towarzysząca prowadzonej na sąd Helenie dodatkowo zdaje się podsycać, zagęszczać atmosferę zbliżającej się śmierci:

W niskiej i ponurej sali, do której żaden otwór dziennego światła nie dopuszcza, stoi w samym środku długi stół czarnym przykryty kobiercem; na nim krucyfiks i kilka ksiąg zbutwiałych. U sklepienia zawieszony kaganiec, odbija krwawe światło od ścian szkarłatnym suknem powleczonych.

(Przeznaczenie, t. 2, rozdz. X, s.117) 
Wrażenie wzniosłości wynikające z grozy i trwogi wznieconych wizerunkiem śmierci wynika nie tylko z jej obrazu. Nasila je odpowiednia stylizacja językowa. Kreacji dziewiętnastowiecznych gotycyzmów zazwyczaj obca jest prostota stylu. Bywa on przejaskrawiony, zawikłany, kunsztowny, a zarazem posępny; obficie wzbogacony ciemnymi epitetami. Koncentruje się głównie na opisach ewokujących grozę. W przedstawionym fragmencie występują charakterystyczne, gotyckie określenia:

— „niska, ponura sala”;

— „czarny kobierzec”;

— „krwawe światło”;

— „szkarłatne ściany”

zastosowane, by wywołać w czytelniku uczucie empatii wobec doznań postaci towarzyszących takim okolicznościom czasu i miejsca. Było to gwarancją właściwego odbioru powieści gotyckiej.

Helena zostaje pogrzebana za życia w klasztornych podziemiach, będących zarazem miejscem wiecznego spoczynku zakonnic, jak i zakonników. Odbiorca spodziewa się, że wtrącona do lochu dziewczyna, która znalazła się w takim otoczeniu, nie zdoła się z niego wydobyć, tak jak nie miałaby sposobności powrotu, trafiając do mitologicznej krainy umarłych.

Scena ta jest twardym dowodem braku oryginalności zarzucanego polskim powieściom gotyckim. Jest ona bowiem schematem wprost przeszczepionym z Mnicha Matthew Gregory'ego Lewisa, gdyż Rautenstrauchowa „skazała swoją bohaterkę na zamurowanie żywcem w podziemiach klasztoru, podobnie jak to z Agnes uczynił Lewis" ${ }^{17}$.

Według Drabikowskiej:

I w tym przypadku skazana na śmierć najpierw została ogłoszona światu jako umarła. Gdy się budzi, pierwszą rzeczą, której dotyka w ciemnościach, jest rozkładająca się głowa. Zdaje sobie sprawę, że została żywcem pogrzebana ${ }^{18}$.

Agnes znalazła się w ogromnej krypcie:

Wzdłuż ciągnęły się szeregiem grobowce podobne temu, z którego się właśnie wydostałam, i wydawały się dość głęboko zapadnięte w ziemię. $Z$ sufitu zwisała na żelaznym łańcuchu nagrobna lampka i rzucała na loch ponure światło. Wszędzie dookoła widać było emblematy śmierci: czaszki, piszczele i inne śmiertelne członki rozrzucone były tam i sam po wilgotnej polepie ${ }^{19}$.

Od momentu uwięzienia, zarówno w przypadku Lewisowskiej Agnes, jak i Rautenstrauchowskiej Heleny, ich egzystencja staje się nieprzerwanym obcowaniem ze śmiercią — przed obiema staje widmo zagłodzenia. Chociaż obie uwolnione zostają z lochów przez braci, to jednak, w przeciwieństwie do Agnes, Helena nie jest już w stanie powrócić do świata żywych.

${ }^{17}$ Z. Sinko, Wstęp, [w:] M. G. Lewis, Mnich, przekł. Z. Sinko, Wrocław 1964, s. LXXII-LXXIII.

${ }^{18}$ M. Drabikowska, dz. cyt., s. 157.

${ }^{19}$ M. G. Lewis, Mnich, przekł. Z. Sinko, Wrocław 1964, s. 440. 
Wyniesiona na powietrze Helena, długi czas przytomności odzyskać nic może; podnosi na koniec powieki, lecz ciemnością ścieśniona źrzenica światła nie znosi, a dusza boleścią zgnębiona całego szczęścia swego ani roskoszy ogarnąć niezdolna. Resztę pozostałych w pamięci wyrazów, bez żadnego związku zbłąkaną tylko myśl kreślą.

(Przeznaczenie, t. 2, rozdz. XIII, s. 160)

Natomiast śmierć ukazana w Matyldzie i Danile Anny Mostowskiej wydaje się mieć zgoła inne proweniencje — groźnych i bezwzględnych mocy nadziemskich ${ }^{20}$.

W utworze Mostowskiej, według Drabikowskiej:

Bohaterem na równych prawach z postacią literacką jest średniowieczny zamek. Budowla ta, będąca najczęściej ruiną, to przestrzeń amorficzna, labiryntowa i klaustrofobiczna, choć — paradoksalnie — często ogromnych rozmiarów. Jednocześnie martwa, ale implikująca utajoną, groźną bądź wstrętną żywotność, objawiającą się na przykład obecnością nadnaturalnego ${ }^{21}$.

W obrazowaniu tej przestrzeni zaciera się więc granica pomiędzy żywym a nieożywionym. Samo otoczenie tajemniczego zamku Mendoga emanuje grozą śmierci. Ruiny oddalone są bowiem od terenów zamieszkanych. Brak tu żywej duszy, ludzie celowo omijają tę nieprzyjazną okolicę.

Należy na tym etapie skierować uwagę na zręczne posługiwanie się charakterystycznymi gotyckimi detalami, jakimi są światło i mrok (migocząca poświata księżyca towarzysząca wędrówce do starożytnego zamku naznaczonego piętnem zbrodni): „Jednego wieczoru, gdy miesiąc niewypowiedzianie oświecał te okolice" (Matylda i Daniło, s. 25) ${ }^{22}$; blask przeświecający przez szczelinę rozpadającego się zamku: „[...] i zdało mi się jakbym jakieś blado i ulatujące światełka ujrzała” (Matylda i Daniło, s. 25); dźwięku: „[...] usłyszałem jakiś szmer wpośród tych murów, mniemałam z począt$\mathrm{ku}$, iż to były nocne puszczyki, sowy, lub jakie inne stworzenia podobnego rodzaiu, które te głosy sprawowały, lecz huk co raz bardziej się pomnażał" (Matylda i Daniło, s. 25); a szczególnie ruchu — co potęguje wrażenie nieuporządkowania, motywu niejednokrotnie używanego przez autorów romansów gotyckich jako wywołującego grozę powstałą w wyniku utraty bezpieczeństwa, jakie zapewnia harmonia ujarzmiająca przestrzeń, czyniąc ją optymalną dla ludzkiej egzystencji.

Wprowadzenie w przestrzeń naznaczoną zbrodnią dokonuje się stopniowo. Z obserwowanego przez czytelnika otoczenia ewokuje estetyka śmierci w swym wymiarze jak najbardziej makabrycznym.

Funkcję wtajemniczenia, a zarazem ostrzeżenia, pełni tu słowiański napis:

Tu tysiące ludzi życie postradały,

Sprawiedliwe nieba zbrodnię ukarały

(Matylda i Danito s. 55)

\footnotetext{
${ }^{20} \mathrm{Na}$ temat powieści Matylda i Daniło Anny Mostowskiej pisałam szerzej w: "Matylda i Danito« — zapomniana powieść Anny Mostowskiej, „Studia Słowianoznawcze” 2011, t. 9, s. 379-405.

${ }^{21}$ M. Drabikowska, dz. cyt., s. 156.

${ }^{22}$ A. Mostowska, Matylda i Danito, [w:] taż, Moje rozrywki, Wilno 1806, s. 25 (pozostałe cytaty z tego wydania).
} 
Groza w tym momencie zyskuje wymiar nierzeczywisty i ponadzmysłowy, nie jest wynikiem zwykłej ludzkiej imaginacji czy też choroby — obłędu. Wprowadzona jest w sposób niezrozumiały, irracjonalny. $Z$ przestrzenią grozy nasyconą atmosferą śmierci zaznajamia bohaterkę istota fantastyczna, upiór będący sprawcą makabrycznych mordów. Stan przerażenia obszarem naznaczonym piętnem zbrodni i spotkaniem z istotą metafizyczną opisuje Mostowska, używając zmetaforyzowanej frazeologii:

Strach i podziwienie ścieły krew w żyłach moich, jednak widząc się pod przemocą jestestwa mocniejszego nade mnie, sądziłam iż przeciwić się woli jego, byłoby rzeczą próżną [...]

(Matylda i Danito, s. 40)

Za pośrednictwem widma Gryzalda dokonuje przerażającego odkrycia w jednym z krzyżackich zamków, w okrągłej salce, gdzie „krew mury miejsca tego farbowała, spróchniałe kości podłogę okrywały” (Matylda i Daniło, s. 55). Lęk kobiety zwiedzającej celę śmierci wzmacnia nocna pora i charakterystyczna gotycka przestrzeń zawiłych korytarzy, ciasnych schodów, spróchniałych drzwi, skrytego dziedzińca, zamurowanych wrót, nagromadzonych skarbów, a w końcu starego pergaminu z zapisaną historią zbrodniarki.

Owa morderczyni — Edgwarda — w idealny sposób realizuje wzorzec „gotyckiego łotra”, czego dowodzą jej dzieje:

Używając na złe nadzwyczajnej swojej piękności, wabiła najbogatszych i najsławniejszych rycerzy, których omamiając rozkoszą, wyciągała po nich niezmiernych darów, a gdy wszystko z nich wyczerpała, trucizną albo mordem, lub innym okrutnym sposobem, ich się pozbawiła, i tak zebrała te ogromne bogactwa.

(Matylda i Danito, s. 46)

Realizuje ona więc podstawowe wymogi, by móc określić ją tym mianem: jest złoczyńcą, którego nękają wyrzuty sumienia, pojawia się w postaci zjawy przybierającej potworną fizjonomię „wybladłego trupa”; pogoń za dobrami materialnymi popycha ją do przekraczania wszelkich zasad etycznych; oprócz tego pojawia się w koszmarnej i ezoterycznej przestrzeni zamkowych ruin.

Nietuzinkowy styl prezentacji Edgwardy jako diabolicznego niegodziwca niekoniecznie był oryginalnym zamysłem Mostowskiej, gdyż straszydło z Matyldy i Daniły ma swoje literackie prototypy. Konstanty Wojciechowski reprezentuje pogląd, iż projekt widma mógł być imitacją postaci z powieści niemieckiej Die blutende Gestalt mit Dolch und Lampe $e^{23}$.

Zofia Sinko przypuszcza, że geneza wykreowania figury pokroju Edgwardy ma inne źródło, a jest nim Mnich Lewisa, którego rozsmakowana we francuskich i angielskich romansach grozy Mostowska niewątpliwie studiowała w oryginale. Postacią z powieści Lewisa, z którą można by zestawić upiora z dzieła Mostowskiej, jest „brocząca krwią zakonnica”. Historia mniszki, zdaniem Zofii Sinko,

${ }^{23}$ K. Wojciechowski, Przedmowy do pierwszych powieści polskich XIX w., „Pamiętnik Literacki” 1905, s. 269. 
[...] istotnie przypomina w ogólnym zarysie dzieje Edgwardy; i jeden, i drugi upiór pokutuje za grzechy, i jednemu, i drugiemu dla osiągnięcia wiecznego spokoju potrzebna jest pomoc i ofiarność żywych ${ }^{24}$.

Edgwarda pokutująca jako zjawa w ciągu kilku wieków wreszcie osiąga ułaskawienie. Godzi się wrócić pamięcią do popełnionych przez nią występków:

[...] uwodziła, pozbawiała życia i okradała spragnionych jej łask rycerzy. Poza tym, co równie ważne, zginęła nagle, nie pojednawszy się z Bogiem na łożu śmierci. Wiele wskazuje na to, że autorka "Stracha” podziela poglądy niektórych przedstawicieli swej epoki, zaprzeczając istnieniu wiecznej kary dla najbardziej zatwardziałych grzeszników ${ }^{25}$.

W rzeczywistości odbiorca ma świadomość, że jest ona sprawczynią licznych łajdactw i że usiłuje odpokutować za pomocą własnej rodziny swoje przewinienia. Jednakże nic nie wiadomo o tym, jakiego rodzaju emocje miały władzę nad fatalną kobietą przed dopuszczeniem się bestialstwa i co odczuwała później, czy był to niekłamany żal, czy być może intencja pokuty za pośrednictwem naiwnej Matyldy jest podszyta jedynie lękiem przed wiecznym potępieniem. Tego rodzaju uściślenie dążeń Edgwardy nie jest możliwe, gdyż zaniechała w powieści żmudzkiej „pogłębionych procesów psychiki bohaterów [oraz] głębszej analizy ich wewnętrznych doświadczeń, związanych z poczuciem niepewności i lęku”26.

Motyw zabójstwa tak naprawdę nie jest dla autorki szczegółem pierwszej wagi. Dzieje Edgwardy potraktowano wyłącznie jako wzór umoralniający. Podobnie jak w Raganie, tak i tu „nieba piorunem pasmo życia Edgwardy przerwały dla położenia tamy tylu okropnym występkom” (Matylda i Daniło, s. 47). A zatem „Świat nadprzyrodzony istnieje w tej powieści jako siła decydująca o losach ludzkich, wyznaczająca ich bieg" ${ }^{27}$. Moce nadprzyrodzone w przypadku Matyldy i Danity unicestwiają pomyślność i życie ludzi.

Również śmierć Daniły (który jako jedyny w powieściowej fabule reprezentował pragmatyczny, racjonalny sposób myślenia, wobec tego rozmijał się z ideałem rycerskiego panicza, tkliwego amanta, a brnął w stronę hulaki, libertyna, propagującego oświeceniową myśl o braku wiary w życie duchowe, w istnienie zaświatów), ma naturę niewytłumaczalną, metafizyczną, irracjonalną, niepojęta, w chwili, gdy dostrzegamy ciało martwego chłopca po jednej z uczt. To siły ponadzmysłowe w przypadku $\mathrm{Ma}$ tyldy i Danity marnotrawią pomyślność i życie ludzi. Postępowanie wbrew ich woli bohaterowie opłacają śmiercią jak tutaj Daniło. Przejawia on oświeceniową ignoran-

${ }^{24}$ Z. Sinko, Powieść angielska osiemnastego wieku a powieść polska lat 1764-1830, Warszawa 1961, s. 152 .

${ }^{25}$ A. Śniegucka, Zjawy i ruiny spotecznie użyteczne. O problematyce wartości w prozie Anny Mostowskiej, Łódź 2007, s. 97.

${ }^{26}$ Z. Sinko, Gotycyzm, [w:] Stownik literatury polskiego oświecenia, red. T. Kostkiewiczowa, wyd. 2 poszerz. i popr., Wrocław 1991, s. 161.

${ }_{27}$ B. Jadczak, Z problemów fantastyki gotyckiej w powieściach Anny Mostowskiej, „Folia Societatis Scientarum Lublinensis", vol. 21, Warszawa 1979, s. 41. 
cję wobec przekonania o istnieniu życia pozagrobowego wbrew widocznym znakom i ostrzeżeniom:

[Daniło] chciał okno zamknąć i wtem usłyszał te słowa, nieroztropny, porzuć myśleć o przedsięwzięciu, które zguby twojej stanie się przyczyną, jeśli natychmiast go nie zaniechasz, nie zezwalają nieba na twój związek z Matyldą.

(Matylda i Danito, s.63-64)

Wedle ludowych przekonań i opowieści gwałtowna śmierć miała być karą niebios za bezbożność bohatera: „W ten oto powieściowo naiwny sposób oświeceniowy libertynizm przełamany zostaje przez preromantyczny demonizm" 28 .

Ukazanie się widma Edgwardy jest więc jakby poświadczeniem przekonania o wpływie fatum ciążącego nad ludzkim losem, znakiem, iż człowiek nie ma sprzyjających okoliczności do wygranej w konfrontacji z siłami nadprzyrodzonymi, tajemnicą przeznaczenia.

Upiór staje się tu personifikacją tajemnych sił władających losami człowieka, tym bardziej że nie posiada on własnej woli, ale odgrywa rolę medium przekazującego istotom ziemskim wyższe wyroki. Osoby takie jak Daniło skazane są na przegraną w walce, jaką toczą z fatum o swoje prawo do szczęścia.

Wprowadzająca nowy gatunek powieści jeszcze u schyłku XVIII wieku Anna Mostowska czy też jej następczyni Łucja Rautenstrauchowa, których twórczość naznaczona była jeszcze reliktem przeszłości, śmiało czerpią z tendencji oświeceniowych. Wszystkie sceny śmierci występujące w ich powieściach, choć przepełnione irracjonalnymi, fantastycznymi elementami zwiastującymi już romantyzm, mają jednak oświeceniową proweniencję. Na ogół wiążą się z dążnością do moralizacji. Zgodnie z tymi wyznacznikami bohaterów dobrych spotyka nagroda, natomiast tych złych nie ominie zasłużona kara w postaci nieprzewidywalnej śmierci, z którą często wiążą się działania sił nadprzyrodzonych lub która jest realizacją zasłyszanej przepowiedni.

Tym samym obie pisarki zdawały się przestrzegać:

[...] kodeksu obowiązującego całą ówczesną literaturę polską, a zawierającego m.in. postulaty dydaktyzmu o charakterze ogólnym i patriotycznym, kreacji i popularyzacji wzorców rycerskich, postulat łączenia piękna i cnoty ${ }^{29}$.

Zgodnie z tendencją dydaktyczną poddawały one waloryzacji postępowanie bohaterów, zestawiając ich na zasadzie dobro-nagroda, zło-kara, zgodnie z „klasycystyczną prawdą o nierozłączności piękna i cnoty, winy ukaranej i cnoty nagrodzonej” ${ }^{30}$.

Trudno mówić o wzniosłych obrazach śmierci i jakiejś ponadwymiarowej prawdzie w nich zawartej, skoro dla Mostowskiej każde dzieło należy uznać za wartościowe, jeżeli tylko „zasady cnoty i prawdziwej moralności w sobie zawierała”31.

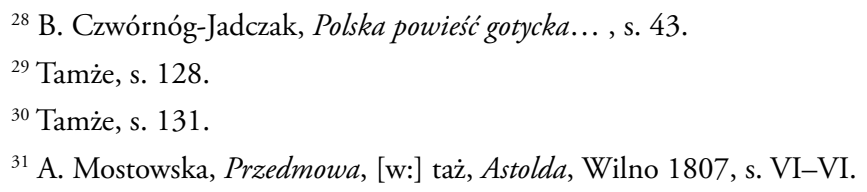


Takie kryterium sprawia, że nie ma tak u Mostowskiej, jak i Rautenstrauchowej opisów i analiz psychiki, wewnętrznych przeżyć zwyrodnialców, psychologicznej charakterystyki postaci:

[...] schematyzm, stereotypowość, wszechobecny dydaktyzm, tendencja do eliminowania charakterystyczności na rzecz typowości doprowadza w literaturze polskiej do ograniczenia oddziaływania filozoficznych konwencji gotycyzmu — ważnego i atrakcyjnego instrumentu poznania świata i człowieka, wydobycia jego najskrytszych myśli i marzeń, a także ciemnych spraw ludzkiego wnętrza ${ }^{32}$.

Co za tym idzie, cechy gatunkowe są tu traktowane bardziej powierzchownie, pisarki dbają jedynie o nietuzinkową akcję i przestrzeń napawającą strachem. „Zwrot ku wewnętrznym procesom psychicznym, jeśli istnieje, nie zmierza w kierunku uczynienia psychiki bohaterów terenem penetracji artystycznej”33.

Romans grozy ewoluował niestety w kierunku rozrywki lekkiej i dostępnej dla szerszego kręgu odbiorców (czego świadectwem jest choćby twórczość Jane Austen). W tej literaturze wyraźnie widać deficyt pewnej uniwersalnej idei. Twórcy stosowali wyłącznie oczywisty, określony zasób narzędzi, których celem było jedynie wyzwolenie grozy.

Wynikająca z uczucia strachu i przerażenia śmiercią specyficzna wzniosłość stała się jednak impulsem w niedalekiej przyszłości do snucia przemyśleń nad wewnętrznymi przeżyciami człowieka i w miarę upływu czasu zapoczątkowała korowód postaci o właściwościach definiowanych jako „romantyczne”: niedopasowanych do rzeczywistości buntowników, występujących przeciwko panującym zasadom, bohaterów, którzy zatracali się w swojej samotności. Spuścizną wzniosłych założeń romansu gotyckiego stała się powieść romantyczna podejmująca tematy egzystencjalne, gdzie uwagę przykuwa jednostka, nie zaś romantyczny kadr stanowiący na początkowym etapie zasadniczy wskaźnik rozpoznawczy gotycyzmu.

Monika Kusek

The Theme of Death in the Novels of Anna Mostowska and Łucja Rautenstrauchowa

Summary

In the gothic novel in the late 18th and early 19th centuries scary death scenes were very common. The writers from the period usually described the scenes of death in a very naturalistic way. Some of them probably wanted to implement Edmund Burke's theory, according to which the fear of death is the most intensive expression of terror. We must experience it in order to be able to know the feeling of sublimity.

The subject of my thesis is the writing of Anna Mostowska and Łucja Rautenstrauchowa. The first of them was the one who introduced the gothic novel as a new genre at the end of the 18th century. There have been analyzed the scenes of death occurring in their novels. Even though they were full of irrational, fantastic elements already announcing Romanticism, yet they had their origin in the Enlightenment. The following pictures of death are connected with the tendency to moralization and didacticism. In accordance with the rules, the good people are rewarded, and the bad ones are punished with unexpected death, that is often caused either by the influence of supernatural forces or by the realization of a prophecy.

\footnotetext{
${ }^{32}$ B. Czwórnóg-Jadczak, Polska powieść gotycka..., s. 131.
}

${ }^{33}$ Tamże, s. 132. 